\title{
Identify factors affecting business efficiency of small and medium enterprises (SMEs): Evidence from Vietnam
}

\author{
Thi Cam Thanh Tran ${ }^{a}$ and Ngoc Tien Nguyen ${ }^{a *}$
}

${ }^{a}$ Faculty of Economics \& Accounting, Quy Nhon University, BinhDinh, Vietnam

\begin{tabular}{l}
\hline C H R O N I C L E \\
\hline Article history: \\
Received: June 12, 2019 \\
Received in revised format: June \\
292019 \\
Accepted: July 5, 2019 \\
Available online: \\
July 5, 2019 \\
\hline Keywords: \\
Efficiency \\
Business efficiency \\
Small and medium enterprises \\
Vietnam
\end{tabular}

\section{Introduction}

There are several empirical studies on business managers and small and medium enterprises for identifying factors that affect business performance in small and medium enterprises. In Vietnam, this study is carried out a typical survey mainly in Binh Dinh Province, Vietnam. In order to do this research, the authors selects the convenient sampling and carry out the surveys with 100 business managers (including business managers at state departments and management leaders) and 400 small and medium enterprises in Binh Dinh, Vietnam. The purpose of conducting a survey on these two target groups is to examine whether or not there is any differences or similarities in identifying factors affecting business performance in small and medium enterprises in Vietnam. According to the result of this survey, for the business managers, 91 out of 100 samples provide valid respondents, accounting for $91 \%$. For the enterprises, we also conduct the survey on different enterprises from various fields: agriculture - forestry and

\footnotetext{
* Corresponding author.

E-mail address: nguyenngoctien@qnu.edu.vn (N. T. Nguyen)

C 2019 by the authors; licensee Growing Science, Canada doi: $10.5267 /$ j.msl.2019.7.007
} 
fisheries, industry and construction, trade and services that are clarified in the economic sector in Vietnam (Government, 2018). There are 376 valid votes out of 400 questionnaires distributed, making up $94 \%$.

In part two, in order to evaluate and compare groups of factors affecting business performance from the standpoint of business managers and small and medium enterprises, we identify possible factors that may affect business performance in businesses through the research overview. The third part of the paper presents the research methodology including data collecting methods for research, research samples and methods for conducting research data analysis. In the fourth part, we describe the sample statistics to study and present the research results of factors affecting business performance from the perspective of enterprise managers and the perspective of enterprises to see the similarities and differences in the judgment of these two target groups. Discussions on the research results are presented in detail in the fifth section; Finally, the sixth part is the conclusion of research results.

\section{Research overview}

The issues related to the factors affecting business performance of businesses in general and small and medium enterprises in particular have been researched and published by many researchers; However, depending on the research objectives, the factors affecting business performance of enterprises considered are different between studies. Indarti and Langenberg (2004) researched on factors affecting business success of small and medium enterprises in Indonesia shows that marketing, technology and access to capital sources had positive impacts on business success of enterprises. This research also suggested that business managers should pay attention on improving the marketing strategies, the technological innovation and the access to capital for the business activities. Along with this research direction, Chittithaworn et al. (2011) in Thailand showed that there were eight factors affecting the business success of small and medium enterprises, including: characteristics of small and medium enterprises, management and know-how, products and services, customers and markets, ways of doing business and cooperation, resources and finance, strategy and external environment. At the same time, Kamunge et al. (2014) concluded that access to finance and the availability of management experience are factors that have important impacts on business performance of enterprises in Limuru Town, Kenya. In addition, factors such as access to business information, access to infrastructure and government policies and regulations also have positive impacts on business performance of enterprises. In the view of the above studies, Philip's (2010) study in Bangladesh also showed that factors such as management capacity, products and services, cooperation, resources, finance, business environment are important for the business success of small and medium enterprises in Bangladesh. In terms of the impact of the factors, the results of regression analysis show that products and services, business practices, management knowhow and external environment are the most influential factors. From the above studies, although studies are conducted in different economies, beside the different factors, there are similar factors affecting the success of business of small and medium enterprises.

In other perspectives, the study of Arshad and Arshad (2019) on the relationship between internal capacity and business performance of small and medium enterprises in the textile and garment industry in Pakistan shows that the adaptability and operational efficiency have significant impacts on the business performance of small and medium enterprises. In addition, Alshanty et al. (2019) studied the impact of market perception in the creative process, knowledge processing and product innovation in small and medium enterprises in Jordan and reported that that the ability to feel market of an enterprise was very important for improving business performance; thereby requiring them to invest in learning to improve business efficiency. Udriyah (2019) performed a survey on market orientation and innovation for competitive advantage and business efficiency of enterprises and reported that market orientation and innovation accounted for $46.3 \%$ of the competitive advantage, while the remaining $54.7 \%$ was affected by fluctuations of other factors. This shows that market orientation and innovation have significant impacts 
on business performance both directly and indirectly through competitive advantage. Chong et al. (2019) studied on the internationalization and renewal of balanced score cards to assess the performance of small and medium enterprises in Malaysia on aspects of knowledge and beliefs, commitment and development opportunities, which could benefit the business performance of enterprises in Malaysia. From these studies, it can be seen that due to different approaches to factors affecting business performance, there are many factors affecting business performance, including internal and external factors of the business. In Vietnam, there have been a number of studies like Tien and Manh (2018) on the factors affecting the business performance of small and medium enterprises and suggest that factors associated with the investment structure of assets or Investment capital for assets such as equity or liabilities affect the business performance of small and medium enterprises. Hang (2015) also showed a relationship between liabilities and business performance in Vietnam, when small and medium enterprises increase capital resources from debt, this could reduce the business performance, showing that businesses have not applied financial leverage in business activities. At the same time, Cong (2018), Quang (2017), Binh (2010) also show that there are many internal factors such as the labor force, asset structure, nature of the business sector and external enterprises' factors such as business environment, infrastructure, government policies that influence on the business performance of enterprises.

From the studies mentioned above, the authors performed some interviews with some expert and found 23 possible factors affecting the business performance of small and medium enterprises in Vietnam and implement correlation verification and analysis of EFA to identify groups of factors that really affect business performance in small and medium enterprises in Vietnam.

\section{Research methods}

\subsection{Data collection methods}

\section{Sources of data}

The data source for the study was directly surveyed by investigating methods and expert methods through questionnaires. The authors designed the survey questionnaire to collect survey opinions from the subjects such as senior and middle managers in small and medium enterprises in Vietnam by performing direct interviews with state managers on enterprises in Vietnam.

\section{Subjects of Data collection}

The authors used convenient sampling methods and carried out on 2 main research groups, namely: (1) business managers and (2) small and medium enterprises in business areas including: agriculture - forestry and fisheries, industry and construction, trade and services according to business sectors in Vietnam.

\section{Collection method}

The primary method used to collect data is: (1) to directly submit questionnaires and (2) to submit questionnaires via the Google Form application. In addition, the authors also met people directly to performed the interview with business managers to identify qualitative reasons to complete the survey questionnaire for research.

\section{Data collection}

The author collected data through the questionnaire with a pre-designed questionnaire. The last questionnaire was developed based on three phases: stage 1- designing draft questionnaire; phase 2- consult- 
ing expert's opinions on draft questionnaires to complete questionnaire indicators and phase 3,- designing the official questionnaires. The questionnaire focused on assessing the factors affecting business performance in small and medium enterprises in Vietnam. In order to serve the question and answer process, the authors used Likert scale (5 options). Levels of impact assessment on this scale are as follows: 1 = "very low", 2 = "low", 3 = "average", 4 = "high", 5 = "very high".

\subsection{Methods for processing and analyzing data}

The total number of 473 valid questionnaires were collected where 97 belong to business managers and 376 belong to small and medium enterprises. After collecting the necessary data, the authors transfer them into Excel, code the variables in each section and each group of the questionnaire. Next, we put all data into SPSS 22.0 software. In the process of data processing and analysis, the authors conduct a number of analysis and testing on SPSS software as follows:

\section{Sample statistics}

The purpose is to do statistics and calculate the percentage of research samples according to the criteria of evaluation, classification, etc.

\section{Descriptive statistics and Average value test}

We use descriptive statistics to calculate the average value for factors affecting business performance. On the other hand, on the purpose of seeing the influence of the factors, we check the average value to evaluate the average of the factors compared with the average value of 3 .

\section{Cronbach's Alpha analysis}

The purpose of Cronbach's Alpha analysis is to test the reliability of the scale and survey data to assess the correlation between observed variables which are the influencing factors in the survey questionnaire to see whether the observed variables are closely related with each other in measuring the impact of test factors on business performance in small and medium enterprises in Vietnam. Most researchers agree that the Cronbach's Alpha levels of 0.8 or higher is good; 0.7 to 0.8 is usable and if the concepts in the question are new, the coefficient is acceptable with 0.6. With Cronbach's Alpha level greater than or equal to 0.8 , the scale is considered as the good measurement, the questions are designed strictly, the scales are really correlated to achieve high reliability (Trong \& Ngoc, 2011). The elimination of variables also follows the principle that Cronbach's Alpha coefficient is eliminated if it is really larger than the Cronbach's Alpha coefficient. When Cronbach's Alpha is $\geq 0.6$, the scale is acceptable in terms of reliability.

\section{EFA exploratory factor analysis}

As we analyze the exploratory factors, researchers often care about some indicators. First, KMO coefficient (Kaiser-Meyer-Olkin) $\geq 0.5$, the significance level of Bartlett test $\leq 0.05$. KMO is one of criteria for the appropriateness of EFA, with $0.5 \leq \mathrm{KMO} \leq 1$, the factor analysis is appropriate. Bartlett's Test is used to examine the hypothesis of the zero correlation between variables in the overall. If this test is statistically significant (Sig $\leq 0.05)$, the observed variables are correlated in the overall. Second, the factor loading coefficients $>0.45$. Any observed variable having the factor loading coefficient $\leq 0.45$ will be disqualified. Third, the scale is accepted when the total variance extracted $\geq 50 \%$ and eigenvalue is greater than 1 . The fourth criterion is the difference in factor loading coefficient of an observed variable between factors which are $\geq 0.3$ to ensure value distinguished between factors (Trong \& Ngoc, 2011). According to Ho et al. (2018), Factor loading is an indicator to ensure the practical significance 
of EFA. Factor loading $>0.3$ is considered to be the minimum, Factor loading $>0.4$ is important, and $\geq$ 0.5 is considered to have practical significance.

\section{Research results}

\subsection{Overview of survey subjects}

\subsubsection{For business managers}

Table 1

Overview of business managers sample

\begin{tabular}{|c|c|c|c|}
\hline & & Count & Subtable N \% \\
\hline \multirow{2}{*}{ Gender } & Male & 67 & $73.63 \%$ \\
\hline & Female & 24 & $26.37 \%$ \\
\hline \multirow{3}{*}{ Business sector } & Industry and construction & 71 & $78.02 \%$ \\
\hline & Trade and services & 17 & $18.68 \%$ \\
\hline & Agriculture, Forestry and fishery & 3 & $3.30 \%$ \\
\hline \multirow{4}{*}{ Qualification } & Bachelor / Engineer & 76 & $83.52 \%$ \\
\hline & Master & 3 & $3.30 \%$ \\
\hline & Doctor & 0 & $0.00 \%$ \\
\hline & Other & 12 & $13.19 \%$ \\
\hline \multirow{3}{*}{ Management position } & Director & 25 & $27.47 \%$ \\
\hline & Vice Director & 56 & $61.54 \%$ \\
\hline & Head of department & 10 & $10.99 \%$ \\
\hline
\end{tabular}

It can be seen from the table that for gender among the 91 managers surveyed, there are total of 67 male, accounting for $73.63 \%$, which is also reasonable when considering the nature of management at enterprises. In the field of enterprises, most business managers working in the industry and construction sectors, have the number of 71 votes, accounting for $78.02 \%$, followed by the field trade and services with the rate of $18.68 \%$ and the lowest is agriculture - forestry - fishery with the rate of $3.3 \%$. This shows that the majority of small and medium enterprises in Vietnam operate in manufacturing, construction, trade and service sectors. In terms of professional qualifications of business managers, it is quite diverse but mainly bachelors / engineers with 76 respondents, accounting for $83.52 \%$, which shows that small and medium enterprise managers in Vietnam have relatively good qualifications. In terms of management, the fact that the majority of respondents are in the position of deputy directors and directors. This shows that the respondents are familiar with the survey objectives.

At the same time, in order to examine the validity of the questionnaire respondents in accordance with the objectives of the survey, the authors questioned the level of interest and information use from business performance of the enterprises. The result is as follows:

Table 2

Evaluate the level of interest and using information from business performance

\begin{tabular}{lccc}
\hline & & Count & Subtable N \% \\
\hline Interest in business performance & Yes & 91 & $100.00 \%$ \\
& No & 0 & $0.00 \%$ \\
\hline \multirow{2}{*}{$\begin{array}{l}\text { Frequency of using information from business per- } \\
\text { formance }\end{array}$} & Very regularly & 62 & $68.13 \%$ \\
& Normally & 20 & $21.98 \%$ \\
& Occasionally & 9 & $9.89 \%$ \\
& Rarely & 0 & $0.00 \%$ \\
\hline
\end{tabular}

Source: collected from research results 
From the data table, it is shown that as the business managers, $100 \%$ of managers surveyed are interested in business performance of enterprises. However, regarding the level of using information from business efficiency to serve the management and administration of enterprises, only $68.13 \%$ of managers used information at a very regular level, $21.98 \%$ of them used regularly and $9.89 \%$ of them used at a normal level. The in-depth interview process shows that although 62 managers use information from business performance very often, it is a periodic use, quarterly or yearly. It is the fact that the small and medium enterprises often prepare the annual financial statements to submit to state management agencies in accordance with government regulations, the preparation of quarterly financial statements is subject to the internal governance requirements at enterprises. This is the reason why using of information on business performance for enterprise management is significantly affected.

\subsubsection{Small and medium enterprises}

For the purpose of preliminary assessment of surveyed enterprises, the authors conducted a survey of information on the business sector, the number of years of operation and the size of enterprises, as well as the level of interest in business performance. The results are as follows:

\section{Field of business}

From Table 3, the majority of enterprises is in the field of industry and construction with the number of 287 enterprises, accounting for $76.3 \%$; the number of enterprises in the field of trade and services is 75, equivalent to $19.9 \%$ and the lowest is the enterprises operating in the field of Agriculture - Forestry - Fisheries, with 14 enterprises, accounting for only 3.7\%. The reason is that in recent years, Vietnam has promoted the development of industrial parks, industrial clusters and economic zones, so it has attracted many manufacturing enterprises, especially in the areas of wood processing, stone processing and animal feed processing, etc.

Table 3

Overview of the business sector of surveyed enterprises

\begin{tabular}{llrrrr}
\hline & Frequency & Percent & Valid Percent & Cumulative Percent \\
\hline \multirow{2}{*}{ Valid } & Industry and construction & 287 & 76.3 & 76.3 & 76.3 \\
& Trade and services & 75 & 19.9 & 19.9 & 96.3 \\
& Agriculture, Forestry and fishery & 14 & 3.7 & 3.7 & 100.0 \\
\cline { 2 - 6 } & Total & 376 & 100.0 & 100.0 & \\
\hline
\end{tabular}

Operating duration

\section{Table 4}

Overview of operating time of surveyed enterprises

\begin{tabular}{lccccc}
\hline & Frequency & Percent & Valid Percent & Cumulative Percent \\
\hline Valid & $1-<5$ years & 15 & 4.0 & 4.0 & 4.0 \\
& $5-10$ years & 235 & 62.5 & 62.5 & 66.5 \\
& $>10$ years & 126 & 33.5 & 33.5 & 100.0 \\
\cline { 2 - 5 } & Total & 376 & 100.0 & 100.0 & \\
\hline & & & Source: collected from research results
\end{tabular}

From the collected data table, in the total of 376 surveyed enterprises, 235 enterprises operator from 5 to 10 years, accounting for $62.5 \%$, followed by over 10 - year enterprises with 126 enterprises, making up $33.5 \%$. This shows that small and medium enterprises in Vietnam have been operating for quite a 
long time, associated with the development of industrial parks and industrial clusters; and with the longterm development, despite their small and medium size, many businesses have very stable market, market share and tendency to develop well in the future.

\section{Size of enterprises}

From Table 5, it can be seen that in the total number of surveyed enterprises, 284 enterprises are mediumsized enterprises, accounting for $75.5 \%$; followed by small-scale enterprises of 76 enterprises, accounting for 20.2\%; enterprises with super small scale are not significant. This shows that the majority of enterprises in Vietnam are medium-sized. This is also entirely consistent with the business sector of enterprises in the surveyed area.

\section{Table 5}

Overview of the size of enterprises

\begin{tabular}{llcccc}
\hline & & Frequency & Percent & Valid Percent & Cumulative Percent \\
\hline \multirow{2}{*}{ Valid } & Small size & 76 & 20.2 & 20.2 & 20.2 \\
\cline { 2 - 6 } & Medium size & 284 & 75.5 & 75.5 & 95.7 \\
\cline { 2 - 6 } & Super small size & 16 & 4.3 & 4.3 & 100.0 \\
\cline { 2 - 6 } & Total & 376 & 100.0 & 100.0 & \\
\hline
\end{tabular}

Level of interest in business performance

\section{Table 6}

Statistics of levels of interest in business performance

\begin{tabular}{lccc}
\hline & & Count & Subtable N \% \\
\hline \multirow{2}{*}{ Interest in business performance } & Yes & 376 & $100.00 \%$ \\
& No & 0 & $0.00 \%$ \\
\hline
\end{tabular}

It can be seen from Table 6 that $100 \%$ of surveyed enterprises are concerned about business performance of enterprises. This shows that small and medium enterprises in Vietnam are very interested in business efficiency to make business decisions. However, even though $100 \%$ of businesses is interested in business performance, the result from the in-depth interviews shows the extent of using information from business efficiency to make management decisions are inconsistent among business groups, even a big difference between businesses in the same business group but different in size, specifically as the following data collection table:

\section{Table 7}

Statistics on the use of information from business performance

\begin{tabular}{|c|c|c|c|c|c|}
\hline & & Frequency & Percent & Valid Percent & Cumulative Percent \\
\hline \multirow[t]{5}{*}{ Valid } & Very regularly & 143 & 38.0 & 38.0 & 38.0 \\
\hline & Regularly & 172 & 45.7 & 45.7 & 83.8 \\
\hline & Normally & 50 & 13.3 & 13.3 & 97.1 \\
\hline & Occasionally & 11 & 2.9 & 2.9 & 100.0 \\
\hline & Total & 376 & 100.0 & 100.0 & \\
\hline
\end{tabular}




\subsection{Results of analysis of factors affecting business performance}

To determine the factors affecting business performance of small and medium enterprises in Vietnam from the perspective of enterprise managers and the perspective of small and medium enterprises, the authors designed a questionnaire with questions in two groups of influencing factors including internal factors such as financial structure, asset investment structure, investment capital structure, cost structure in revenue, the diversity of products and services provided, management ability of leaders. The external factors also include business environment, input market, output market, political institutions, interest of the bank with the total of 23 surveyed variables. The process of implementing Cronbach's Alpha, KMO and Bartlett's Test and EFA analysis gives the following results:

\subsubsection{Perspective of business managers}

The Cronbach's Alpha analysis results in 0.844 with the remaining 14 variables. Next, the authors conducted KMO analysis with the following results:

\section{Table 8}

Test results of KMO and Bartlett's Test

Kaiser-Meyer-Olkin Measure of Sampling Adequacy.

Bartlett's Test of Sphericity Approx. Chi-Square

468.962

$\mathrm{df}$

Sig.

.000

Table 9

The result of the total variation of the explained data

\begin{tabular}{|c|c|c|c|c|c|c|c|c|c|}
\hline \multirow[b]{2}{*}{ Component } & \multicolumn{3}{|c|}{ Initial Eigenvalues } & \multicolumn{3}{|c|}{ Extraction Sums of Squared Loadings } & \multicolumn{3}{|c|}{ Rotation Sums of Squared Loadings } \\
\hline & Total & $\begin{array}{c}\% \text { of Var- } \\
\text { iance }\end{array}$ & $\begin{array}{c}\text { Cumulative } \\
\%\end{array}$ & Total & $\%$ of Variance & Cumulative \% & Total & $\%$ of Variance & Cumulative $\%$ \\
\hline 1 & 4.698 & 33.559 & 33.559 & 4.698 & 33.559 & 33.559 & 3.552 & 25.370 & 25.370 \\
\hline 2 & 2.289 & 16.351 & 49.909 & 2.289 & 16.351 & 49.909 & 2.727 & 19.479 & 44.849 \\
\hline 3 & 1.252 & 8.940 & 58.849 & 1.252 & 8.940 & 58.849 & 1.960 & 14.001 & 58.849 \\
\hline 4 & .942 & 6.727 & 65.576 & & & & & & \\
\hline
\end{tabular}

Source: collected from research results

According to the table of KMO and Bartlett's Test, we have KMO coefficient $=0.785>0.5$ (greater than the minimum level to ensure proper EFA analysis) and the Sig level of Bartlett's test is $0.000<0.05$, which means variables are correlated in overall. The authors' EFA analysis is statistically significant. At the same time, the analytical results show that, in the above variance table, according to Eigenvalue standard $>1$, there are three groups of factors to be extracted. The total variance extracted is $58,849 \%$ (greater than the standard level of $>50 \%$ ), which means $58,849 \%$ of the variability of the data is explained by 3 groups of factors. For Factor Loading coefficients in groups, according to Trong and Ngoc (2011), to ensure the level of practical significance of EFA, Factor Loading $>0.3$ is considered the minimum, Factor Loading $>0.4$ is considered to be important, Factor Loading $\geq 0.5$ is considered to have practical significance. Varimax rotation is used to obtain the best factor loading coefficients, in the point of view of business managers, we obtained three groups of factors affecting the business performance of small and medium enterprises group of outside factors with 6 factors, group of internal factors with 5 factors, group of institutional and infrastructure factors with 3 factors. The detail is shown as below. 
Table 10

Matrix of factor rotation

\begin{tabular}{lcc}
\hline & \multicolumn{2}{c}{ Component } \\
\cline { 2 - 3 } & 1 & 2 \\
\hline Input Market & .775 & 3 \\
Output Market & .773 \\
Business environment (domestic, international, industry) & .773 \\
Available resources & .759 & .715 \\
Other professions and logistics & .663 & .766 \\
Climate, weather & .697 \\
Employee capacity & .671 \\
Cost structure in revenue & .624 \\
The characteristics of the industry businessed & .583 \\
Management ability of leaders & \\
The diversity of products and services & \\
Institutions, politics & & .728 \\
Infrastructure & .592 \\
Tax policies on enterprises & .562 \\
\hline
\end{tabular}

Source: collected from research results

\subsubsection{Perspective of small and medium enterprises}

Cronbach's Alpha analysis results in a value of 0.895 with 17 remaining variables. Next, the authors conducted KMO analysis and gave out the following results:

Table 11

Results of KMO and Bartlett's Test Kaiser-Meyer-Olkin Measure of Sampling Adequacy. Bartlett's Test of Sphericity

\begin{tabular}{lr} 
& .904 \\
Approx. Chi-Square & 2350.688 \\
df & 105 \\
Sig. & .000 \\
\hline &
\end{tabular}

Table 12

The result of the total variation of the explained data

\begin{tabular}{|c|c|c|c|c|c|c|c|c|c|}
\hline \multirow{2}{*}{$\begin{array}{c}\text { Compo- } \\
\text { nent }\end{array}$} & \multicolumn{3}{|c|}{ Initial Eigenvalues } & \multicolumn{3}{|c|}{ Extraction Sums of Squared Loadings } & \multicolumn{3}{|c|}{ Rotation Sums of Squared Loadings } \\
\hline & Total & $\%$ of Variance & Cumulative \% & Total & $\%$ of Variance & Cumulative $\%$ & Total & $\%$ of Variance & Cumulative \% \\
\hline 1 & 5.904 & 39.360 & 39.360 & 5.904 & 39.360 & 39.360 & 3.572 & 23.813 & 23.813 \\
\hline 2 & 2.075 & 13.836 & 53.196 & 2.075 & 13.836 & 53.196 & 3.539 & 23.590 & 47.403 \\
\hline 3 & 1.010 & 6.734 & 59.930 & 1.010 & 6.734 & 59.930 & 1.879 & 12.528 & 59.930 \\
\hline
\end{tabular}

Source: collected from research results

According to the table of KMO and Bartlett's Test, we have KMO coefficient $=0.904>0.5$ (greater than the minimum to ensure proper EFA analysis) and the Sig level of Bartlett's test is $0.000<0.05$, which means variables are correlated in overall. Thus, the authors' EFA analysis is statistically meaningful. At the same time, the analytical results show that, in the variance table above, according to Eigenvalue standard $>1$, there are three groups of factors extracted. The total variance extracted is $59.930 \%$ (greater than the standard level $>50 \%$ ), which means $59.930 \%$ of the variation of the data is explained by 3 groups of factors. For loading factor coefficients in groups, Trong and Ngoc (2011) show that to ensure the practical significance level of EFA, Factor Loading $>0.3$ is considered as the minimum, Factor 
Loading $>0.4$ is considered to be important, Factor Loading $\geq 0.5$ is considered to have the practical significance. The result from the Varimax rotation to obtain the best factor loading coefficient yields three groups of factors affecting the business efficiency of small and medium enterprises in Binh Dinh province, including a group of internal factors with (7 variables), external factors with 5 variables, and the institutional and infrastructure factors with 3 variables. The detail is showed as follow,

Table 13

Matrix of factor rotation

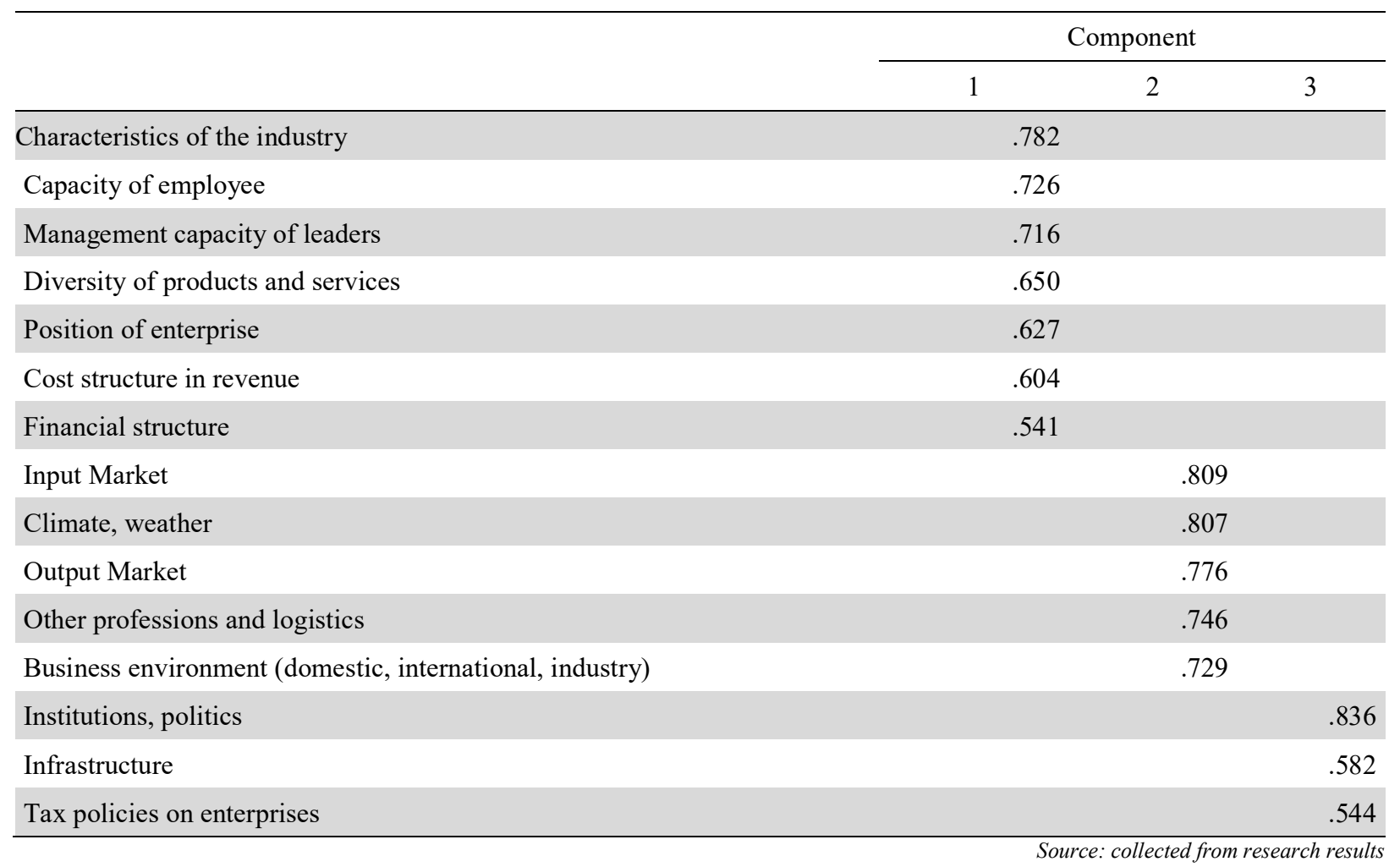

\section{Discussion}

From the above result, it has shown that for the perspective of business managers, there are three groups of factors affecting the business performance of small and medium enterprises in Vietnam, including the group of internal factors with 5 factors, group of external factors with 6 factors and group of institution and infrastructure with 3 factors; For the enterprise perspective, the results have shown that there were three groups of factors including the internal factors of enterprises with 7 factors, group of external factors with 5 factors and group of institutional and infrastructure with 3 factors. Therefore, there are some similarities in terms of the institutional and infrastructure factors between the perspective of managers and enterprises. On the other hand, despite the group of factors is the same, the influencing factors are different between two groups surveyed. It can be concluded that there is a similarity in identifying groups of factors affecting business performance of small and medium enterprises, including (1) a group of internal factors that belong to the enterprises themselves as well as the employee's working ability, the cost structure in revenue, the characteristics of the industry being in business, the management capacity of leaders, the diversity of products / services provided, etc., (2) group of external environmental factors such as input market, output market, available resources, business environment, other industries and logistics services, etc. and (3) group of institutional and infrastructure factors such as institutions, politics, infrastructure, tax policies on businesses. The results of this study have many points in line with Indarti and Langenberg (2004), Chittithaworn et al. (2011), Kamunge et al. (2014), Philip (2010), Arshad and Arshad (2019), Tien and Manh (2018) and Cong (2018). Therefore, in order to improve business efficiency for small and medium enterprises in Vietnam, it is necessary for enterprises to diversify 
their business lines and restructure enterprises to reduce costs and improve abilities and skills for employees in the enterprise. Besides, local authorities and the state should also invest and consolidate infrastructure, create a favorable business environment, support or offer incentives to the small and medium enterprises tax, and plan input and output market networks for these enterprises.

\section{Conclusion}

The discovery of new groups of factors that affect business performance in small and medium enterprises in Vietnam will be an important basis to help small and medium enterprises in Vietnam considering and evaluate the influencing factors and offer appropriate solutions to improve business efficiency. From the results of the EFA analysis, there are three main groups of factors affecting business performance of enterprises, including the group of internal factors such as cost structure in revenue, characteristics industry, management ability of leaders, diversity of products / services provided, etc.; group of external factors, such as input market, output market, available resources, business environment, other industries and logistics service and group of factors belonging to institutions and infrastructure such as institutions, politics, infrastructure, tax policies on enterprises.

\section{References}

Arshad, M., \& Arshad, D. (2019). Internal capabilities and SMEs performance: A case of textile industry in Pakistan. Management Science Letters, 9(4), 621-628.

Alshanty, A., Emeagwali, O., Ibrahim, B., \& Alrwashdeh, M. (2019). The effect of market-sensing capability on knowledge creation process and innovation Evidence from SMEs in Jordan. Management Science Letters, 9(5), 727-736.

Binh, N.T. (2010). Analysis of Business Activities. Statistical publisher. Ha Noi.

Cong, N.V. (2018). Business Analysis. Publishing house of National Economics University. Ha Noi.

Goverment (2018). Report on the Plenary Session, private economic development forum. National Economics University. Ha Noi.

Goverment (2018). Decree No 39/2018/ND-CP detailing some articles of the Law to support small and medium enterprises, issued March 11, 2018. Ha Noi.

Chittithaworn, C., Islam, M. A., Keawchana, T., \& Yusuf, D. H. M. (2011). Factors affecting business success of small \& medium enterprises (SMEs) in Thailand. Asian Social Science, 7(5), 180-190.

Chong, P., Ong, T., Abdullah, A., \& Choo, W. (2019). Internationalisation and innovation on balanced scorecard (BSC) among Malaysian small and medium enterprises (SMEs). Management Science Letters, 9(10), 1617-1632.

Hang, N.T.L. (2015). Discuss the profitability of assets and the profitability of costs in businesses. Journal of Accounting \& Auditing, 144, 13 - 15.

Ho, D.P, Nhi, V.V., \& Phuoc, T. (2018). Quantitative research in Accounting - Auditing. Financial Publishing House, Ha Noi.

Kamunge, M. S., Njeru, A., \& Tirimba, O. I. (2014). Factors affecting the performance of small and micro enterprises in Limuru Town Market of Kiambu County, Kenya. International Journal of Scientific and Research Publications, 4(12), 1-20.

Indarti, N., \& Langenberg, M. (2004). Factors affecting business success among SMEs: Empirical evidences from Indonesia. Journal of Asia Entrepreneurship and Sustainability, 3(2).

Trong, H., \& Ngoc, C.M.N. (2011). Applied Statistics in Social- Economic Analysis. Labour and Social Publising House. Ha Noi.

Tien, N.N., \& Manh, D.D. (2018). Current situation of profitability of assets and equity in small and medium enterprises in Binh Dinh province. Journal of Economics and Forecasting, 33(11), 49-52.

Philip, M. (2011). Factors affecting business success of small \& medium enterprises (SMEs). Amity Global Business Review, 6(1), 118-136.

Quang, N.N. (2017). Business analysis. Financial Publishing House. Ha Noi. 
Udriyah, U., Tham, J., \& Azam, S. (2019). The effects of market orientation and innovation on competitive advantage and business performance of textile SMEs. Management Science Letters, 9(9), 14191428.

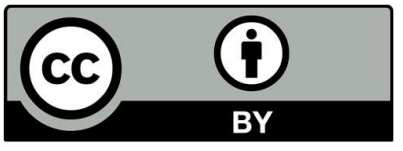

(C) 2019 by the authors; licensee Growing Science, Canada. This is an open access article distributed under the terms and conditions of the Creative Commons Attribution (CCBY) license (http://creativecommons.org/licenses/by/4.0/). 